\title{
Review
}

\section{Limonoids: Overview of Significant Bioactive Triterpenes Distributed in Plants Kingdom}

\author{
Amit RoY* ${ }^{*} a$ and Shailendra SARAF ${ }^{b}$ \\ ${ }^{a}$ GRY Institute of Pharmacy; Vidya Vihar, Borawan-451228, Dist Khargone, MP, India: and \\ ${ }^{b}$ Institute of Pharmaceutical Technology, Ravishankar Shukla University; \\ Raipur, Chhattisgarh, India.
}

Received October 29, 2005; accepted November 12, 2005

\begin{abstract}
The search for limonoids started long back when scientists started looking for the factor responsible for bitterness in citrus which has negative impact on citrus fruit and juice industry worldwide. The term limonoids was derived from limonin, the first tetranortriterpenoid obtained from citrus bitter principles. Compounds belonging to this group have exhibited a range of biological activities like insecticidal, insect antifeedant and growth regulating activity on insects as well as antibacterial, antifungal, antimalarial, anticancer, antiviral and a number of other pharmacological activities on humans. Although hundreds of limonoids have been isolated from various plants but, their occurrence in the plant kingdom is confined to only plant families of order Rutales and that too more abundantly in Meliaceae and Rutaceae, and less frequently in Cneoraceae and Harrisonia sp. of Simaroubaceae. Limonoids are highly oxygenated, modified terpenoids with a prototypical structure either containing or derived from a precursor with a 4,4,8-trimethyl-17-furanylsteroid skeleton. All naturally occurring citrus limonoids contain a furan ring attached to the D-ring, at $\mathrm{C}-17$, as well as oxygen containing functional groups at C-3, C-4, C-7, C-16 and C-17. The structural variations of limonoids found in Rutaceae are less than in Meliaceae and are generally limited to the modification of $A$ and $B$ rings, the limonoids of Meliaceae are more complex with very high degree of oxidation and rearrangement exhibited in the parent limonoid structure. To counter the problem of bitterness in citrus juice and products genetic engineering of citrus to maximize the formation of limonoid glucosides for reducing limonoid bitterness is the focus of recent and future research. Regarding the biological activities of limonoids the investigations are to be directed towards detailed characterization, quantification, and designing a simple as well as versatile synthetic route of apparently important limonoids. Extraction methods too should be optimized; evaluation and establishment of pharmaco-dynamic and kinetic principles, and structure activity relationships should be a key goal associated with limonoids so that they can be safely introduced in our arsenal of pharmaceuticals to safeguard the humanity from the wrath of disease and its discomfort.
\end{abstract}

Key words limonoid; tetranortriterpenoid; citrus; Meliaceae

\section{INTRODUCTION}

The search for limonoids started long back when scientists started looking for the factor responsible for bitterness in citrus. The term limonoids was derived from limonin, the first tetranortriterpenoid obtained from citrus bitter principles. ${ }^{1)}$ In 1938, Highby first isolated limonin from Washington navel orange and showed it as bitter principle of navel orange juice in 1949. ${ }^{2)}$ Ongoing studies show that limonoids are highly oxygenated, modified terpenoids and have recently attracted attention because compounds belonging to this group have exhibited a range of biological activities like insecticidal, insect antifeedant and growth regulating activity on insects as well as antibacterial, antifungal, antimalarial, anticancer, antiviral and a number of other pharmacological activities on humans. ${ }^{3-6)}$ Interest in limonoids research has become greater than before also because some of them are responsible for producing bitterness in citrus fruits, which has negative impact on citrus fruit and juice industry worldwide. $^{7,8)}$

\section{PROPERTIES}

Limonoids are of moderate polarity, insoluble in water and hexane but soluble in hydrocarbons, alcohol and ketone ${ }^{9}$; they are mostly bitter in taste and account for the scent of fresh peels of citrus fruits. Limonoids are present in neutral (noncarboxylated/aglycon) as well as acidic (carboxylated/ glucoside) forms, the former are insoluble and bitter while latter are soluble and tasteless. Chemically they are highly oxygenated triterpenes, classed as tetranorterpenoids. They present, perhaps the most extreme examples of oxidation of triterpenes in nature. ${ }^{1,10)}$

\section{DISTRIBUTION}

Although hundreds of limonoids have been isolated from various plants but, their occurrence in the plant kingdom is confined to only plant families of order Rutales and that too more abundantly in Meliaceae and Rutaceae, and less frequently in Cneoraceae and Harrisonia sp. of Simaroubaceae. The limonoids occurring in Meliaceae are also known as meliacins. Out of over 300 limonoids known to day, about one-third is accounted by neem (Azadirachta indica) and Chinaberry (Melia azedarach) alone. ${ }^{1,10-12)}$

Citrus fruits and its closely related genera contain about 36 limonoid aglycones and 17 limonoid glucosides. ${ }^{13)}$ Citrus limonoids and their glucosides, the water-soluble triterpenoid compounds that occur naturally in citrus fruit and citrus juice in amounts comparable to vitamin $\mathrm{C}$, can be reclaimed from citrus processing and citrus seeds as by-products in large quantities. ${ }^{12)}$ Limonin glucoside is the most abundant of the limonoid glucosides in citrus. ${ }^{14)}$ Azadirachta indica (Neem tree) a species of meliaceae family is a storehouse of 
Table 1. Chief Sources of Limonoids

\begin{tabular}{|c|c|c|c|}
\hline Family & Plant species & Plant part & Reference \\
\hline \multirow[t]{40}{*}{ Meliaceae } & Agalia andamanica & Leaves & 76 \\
\hline & Astrotrichilia vomatata & Stem bark & 77 \\
\hline & Azadirachta indica & Seed oil & 78 \\
\hline & Azadirachta indica & Kernels & 79 \\
\hline & Azadirachta indica & Leaves & 80 \\
\hline & Azadirachta indica & Seeds & 3 \\
\hline & Carapa granatum & Fruits & 81 \\
\hline & Cedrela montana & Fruits and seeds & 82 \\
\hline & Cedrela salvadorensis & Leaves & 66 \\
\hline & Cedrela sinensis & Leaves & 83 \\
\hline & Chukrasia tabularis & Root bark & 84 \\
\hline & Cipadessa fruticosa & Fruits & 85 \\
\hline & Khaya anthotheca & Stem bark & 86 \\
\hline & Khaya grandifolia & Bark and seeds & 50 \\
\hline & Khaya ivorensis & Stem bark & 53 \\
\hline & Khaya senegalensis & Stem bark & 87 \\
\hline & Khaya senegalensis & Fruits & 54 \\
\hline & Melia azedarach & Leaves & 59 \\
\hline & Melia azedarach & Ripe fruits & 88 \\
\hline & Melia azedarach & Kernels & 33 \\
\hline & Melia azedarach & Fruits & 89 \\
\hline & Melia azedarach & Kernels & 20 \\
\hline & Melia dubia & Bark & 90 \\
\hline & Munronia henryi & Whole plant & 91 \\
\hline & Neobeguea leandreana & Stem bark & 92 \\
\hline & Pterorhachis zenkeri & Stem & 93 \\
\hline & Quivisia papinae & Seeds & 94 \\
\hline & Quivisia papinae & Seeds & 95 \\
\hline & Sandoricum koetjape & Leaves & 96 \\
\hline & Sandoricum koetjape & Leaves & 97 \\
\hline & Swietenia mahogany & Stem bark & 98 \\
\hline & Teucrium tomentosum & Aerial parts & 99 \\
\hline & Trichilia emetica & Root & 52 \\
\hline & Trichilia estipulata & Stem bark & 100 \\
\hline & Trichilia havanensis & Seeds & 101 \\
\hline & Trichilia pallida & Roots & 102 \\
\hline & Trichilia rubescens & Leaf & 51 \\
\hline & Turraea floribunda & Seeds & 103 \\
\hline & $\begin{array}{l}\text { Turraea wakefieldii; } \\
\text { T. floribunda }\end{array}$ & Root bark & 30 \\
\hline & Xylocarpus granatum & Stem bark & 104 \\
\hline \multirow[t]{8}{*}{ Rutaceae } & Bouchardatia neurococca & Aerial parts & 105 \\
\hline & Citrus reticulata & Seeds & 106 \\
\hline & Citrus sudachi & Seeds & 5 \\
\hline & Citrus unshiu & Peels & 107 \\
\hline & Clausena excavate & Rhizomes and roots & 58 \\
\hline & Dictamnus dasycarpus & Root bark & 108 \\
\hline & Hortia colombiana & Wood & 11 \\
\hline & Raulinoa echinata & Stems and leaves & 109 \\
\hline \multirow[t]{3}{*}{ Simaroubaceae } & Harrisonia abyssinica & Root bark & 110 \\
\hline & Harrisonia perforate & Leaves & 111 \\
\hline & Harrisonia perforate & Leaves & 112 \\
\hline
\end{tabular}

limonoids containing more than hundred different limonoids and their derivatives in its different plant parts. ${ }^{1,15,16)}$ Other important sources of limonoids in meliaceae family are $\mathrm{Ce}$ drela sp., Khaya sp., Melia azedarach, Sandoricum koetjape, Swietenia mahogany, Trichilia sp. and Turraea sp. (Table 1).

\section{CHEMISTRY AND BIOSYNTHESIS}

Limonoids are stereochemically homogenous compounds, with a prototypical structure either containing or derived from a precursor with a 4,4,8-trimethyl-17-furanylsteroid skeleton ${ }^{6}$; all naturally occurring citrus limonoids contain a

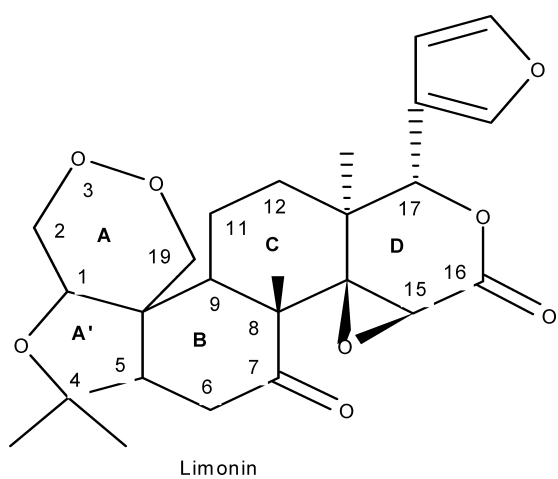

Fig. 1. Citrus Limonoid

furan ring attached to the $\mathrm{D}$-ring, at $\mathrm{C}-17$, as well as oxygen containing functional groups at C-3, C-4, C-7, C-16 and C$17^{17)}$ (Fig. 1). The structural variations of limonoids found in Rutaceae are less than in Meliaceae and are generally limited to the modification of A and B rings, the limonoids of Meliaceae are more complex with very high degree of oxidation and rearrangement exhibited in the parent limonoid structure $^{11,18)}$ (Fig. 2).

Most of the biogenetic proposals are tentative as they are not supported by valid biosynthetic studies and there is only one instance of biosynthetic investigation in neem that of nimbolide in neem leaves. The triterpenes containing a $\mathrm{C}$, side chain at $\mathrm{C}-17$ are supposed to be biogenetic precursors of meliacins and hence are known as protolimonoids or protomellacins or melianes. Meliantriol was the first tetracyclic triterpenyl alcohol biogenetically related to $20(S)$-tirucallol, isolated from both neem oil and the fresh fruits of Melia azedarach.1)

Endo et al., ${ }^{4)}$ Bagge, ${ }^{6}$ Waterman, ${ }^{10)}$ and Suarez et al. ${ }^{11)}$ have illustrated the biosynthesis of limonoids showing that limonoids are synthesized via terpenoids biosynthetic pathway, starting with cyclization of squalene, which results into a tetracyclic ion (Fig. 3); euphane and tirucallane (Fig. 4) two chemically similar compounds may be the ultimate biogenetic precursors. Oxidative degradation at the $\mathrm{C}-17$ side chain of either of these nucleus results in loss of four carbon atoms and formation of $\beta$-substituted furan, further oxidations and skeletal rearrangements in one or more of the four rings, which are designated as A, B, C and D (as shown in Fig. 1), gives rise to different groups of limonoids (Fig. 5) and each group consist of number of limonoids (Fig. 6) possessing a variety of biological activity into their triterpene skeleton. It may be mentioned here that only plants belonging to the family Meliaceae specialize in the production of Cseco meliacins. ${ }^{1)}$

Deacetylnomilinic acid is described as the most likely initial precursor of all the known citrus (Rutaceae) limonoids, which itself may be biosynthesized from acetate, mevalonate and/or furanesyl pyrophosphate in the phloem region of stems. With radioactive tracer work it has been shown that deacetylnomilinic acid converts into nomilin. Both deacetylnomilinic acid and nomilin are synthesized in the phloem region of stem and then are translocated to other plant tissues such as leaves, fruit tissues and seeds. Seed and fruit tissues are capable of biosynthesizing other limonoids starting from nomilin independently, by at least four different path- 

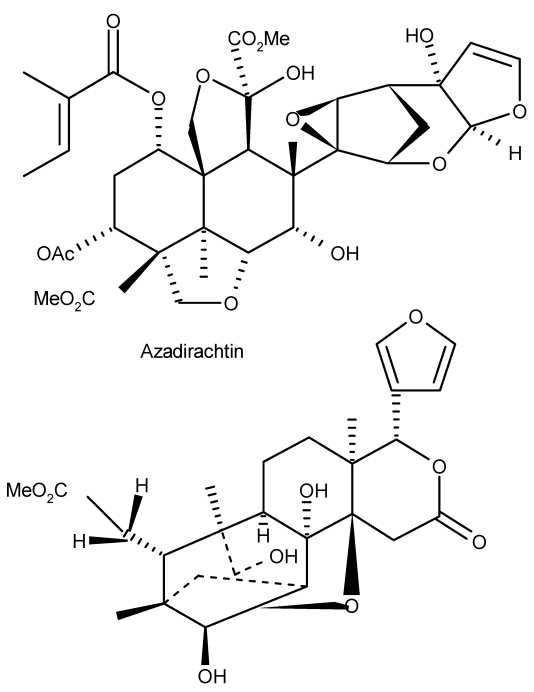

Khayanolide D
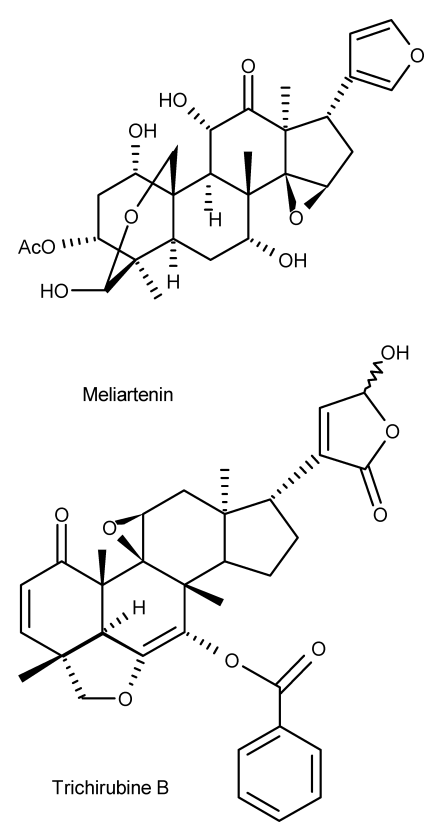

Fig. 2. Examples of Structural Complexicities in Limonoids of Meliaceae

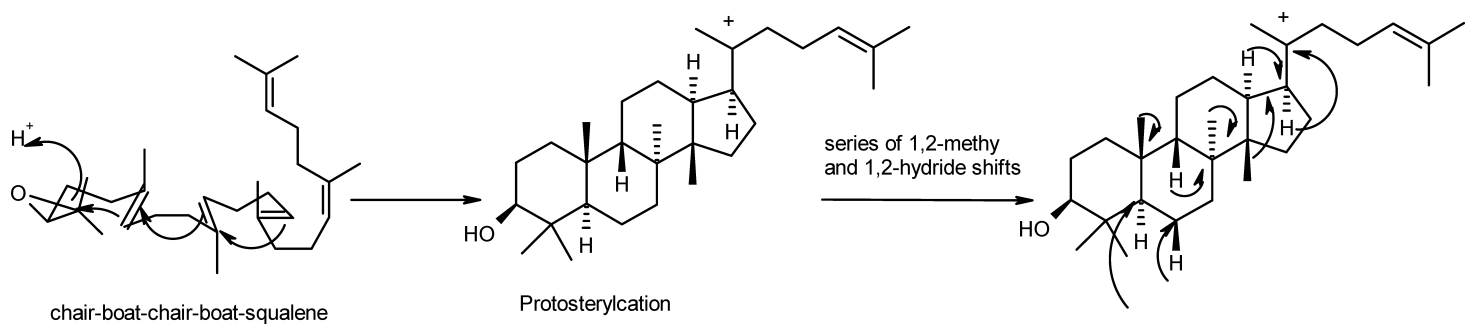

Fig. 3. Squalene Epoxide Leading to Different Intermediate Triterpene Cations

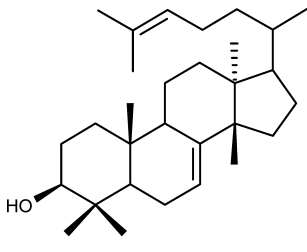

Euphane

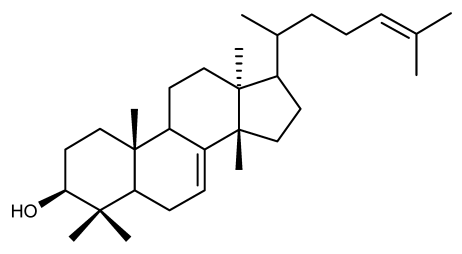

Tirucallane
Fig. 4. Proposed Precursors of Limonoids

ways $^{2,4,7)}$ (Fig. 7).

Major citrus species accumulate limonin, nomilin, obacunone and deacetylnomilin; Citrus ichangensis and relatives accumulate ichangensin (keto and ketal); Fortunella and related species accumulate calamine group limonoids such as calamine and cyclocalamin. Limonoid aglycones are endogenously converted into tasteless limonoid glucosides during fruit maturation. ${ }^{4)}$ Recently a method combining solid-phase extraction and reversed-phase high-performance liquid chromatography has been described for the isolation of two key metabolites, limonoate and nomilinoate A-ring lactones, in the limonoid biosynthetic pathway critical to citrus quality. ${ }^{19)}$

\section{BIOAVAILABILITY OF LIMONOIDS}

Manners et al. ${ }^{14)}$ utilized liquid chromatography/mass spectrometry (LC-MS) to analyze the plasma of four groups of four healthy male and female subjects, administered high doses of pure limonin glucoside, for the presence of limonin to establish the absorption, metabolism, and bioavailability of citrus limonoids to humans. The plasma analysis revealed increasing amounts of limonin associated with increasing doses of limonin glucoside among the subject groups in mean maximum concentration amounts ranging from 1.74 to $5.27 \mathrm{nmol} / 1$. They also observed a high degree of variability in the analyzed limonin concentration within the subject groups. The mean time to maximum concentration was $6 \mathrm{~h}$. A second compound with MS/MS characteristics identical to limonin was detected in amounts up to $5.13 \mathrm{nmol} / 1$ and is hypothesized to be a limonin epimer. Post-study health evaluation established no ill effects among study subjects consuming high doses of limonin glucoside.

\section{ACTIVITIES ON INSECTS}

Several compounds present in plants are of great importance for their use in insect pest management and limonoids from meliaceae have potential to effectively control a variety of insect pests without harming the environment. ${ }^{20)}$ Azadirachtin (Fig. 2) is a $C$-seco limonoid, which was isolated by Morgan in 1968 as an insect antifeedant from the seeds of the Indian Neem tree, is a popular natural bio-pesticide. $^{1,21)}$ Neem protects itself from huge number of pests with a multitude of pesticidal ingredients and so far at least 


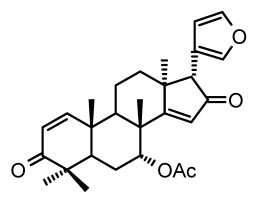

Intact limonoid

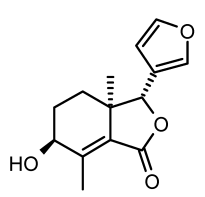

Degraded limonoid
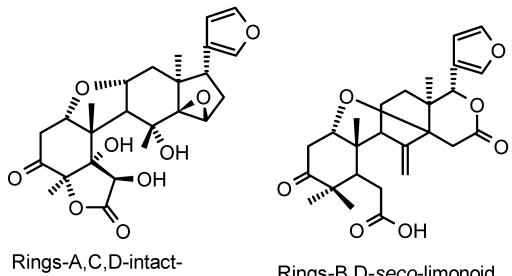

Rings-B,D-seco-limonoid

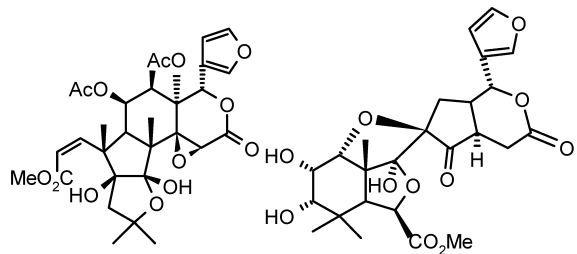

Highly cleaved limonoid

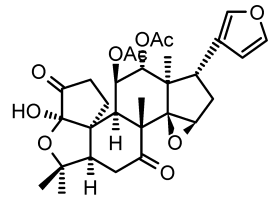

Ring A-seco limonoid

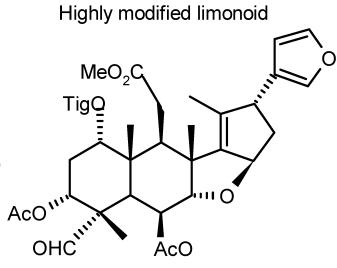

Ring-C cleaved limonoid

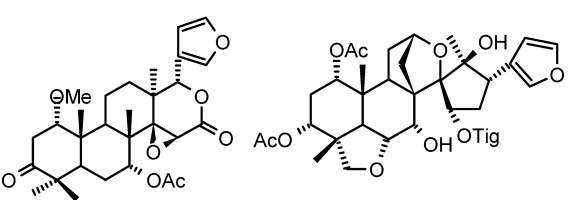

Ring-D-Lactone-limonoid

RingC-seco limonoid

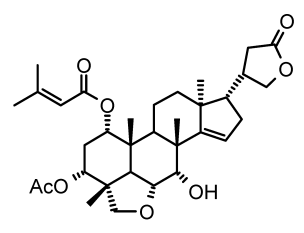

gama-lactone side chain limonoid

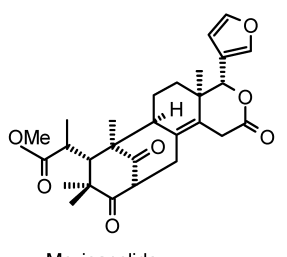

Mexicanolide

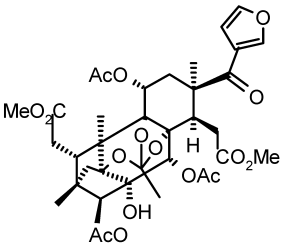

Phragmalin limonoid

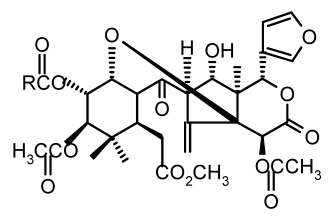

Trijugin-type limonoid

Fig. 5. Types of Limonoids Showing Different Degrees of Oxidation and Skeletal Arrangement

nine neem limonoids have demonstrated an ability to block insect growth affecting a range of species that includes some of the most deadly pests of agriculture and human health; new limonoids are still being discovered in neem but azadirachtin, salannin, meliantriol and nimbin are the best known and most significant. ${ }^{22)}$ Most research that has been done on neem plant has focused intensely on azadirachtin because it is the principal active ingredient of a unique insecticide, which is thought to be the most useful and most fascinating byproduct of the neem tree. It is thought to be so peculiar because of its mode of action: it does not immediately kill the insect like most pesticides do. Instead, when an insect eats azadirachtin, it actively attacks the insect's reproductive cycle, its feeding pattern, its bodily development, as well as acting as a direct toxin. Thus, when azadirachtin is sprayed on the plant and the insect takes a bite, the insect will no longer be able to reproduce, eat, or grow. Because this unique compound only affects the insects that consume it, other "friendly" insects, which may help pollination and other plant functions, are not harmed; it is a "narrow spectrum pesticide." Tests have shown azadirachtin to be effective on at least 200 different insect species. ${ }^{3,23,24)}$ Azadirachtin and related limonoids from neem tree have shown strong antifeedant and growth regulating activity and at the same time these compounds are highly bio-degradable, are very slightly toxic towards non-target organisms, while they are non-toxic towards humans and mammals in general, with very low persistence in systemic action, ${ }^{21,25)}$ this is the reason why an array of insecticides and pesticides comprising of azadirachtin as principal constituent and based on neem extract are available today in the market. Koul et al. ${ }^{26,27)}$ have further shown that azadirachtin being the most active compound in neem is not synergized or influenced by any other limonoid, but other non-azadirachtin limonoids show synergism in specific combination, which may be due to their different modes of action.
Several citrus limonoids and limonin derivatives too have been found to have insect controlling activities on Colorado potato beetle (Leptinotarsa decemlineata) and Spodoptera frugiperda larvae. Citrus limonoids work both as toxins and feeding deterrents. These include limonin, nomilin, and obacunone, epilimonol and limonin diosphenol. ${ }^{12,28)}$ Citrus limonoids have been shown to suppress adult Colorado potato beetle populations due to repellency or dispersal from treated plants and they inhibit ovipositon of Colorado potato beetles due to nutritional disruption caused by limonoid induced antifeedant effects. ${ }^{12)}$ Many more limonoids have been isolated in recent years with antifeedant, insect repellent, growth disrupter, reproduction inhibitor and other insect-controlling activity (Table 2 ).

The extract of neem, azadirachtin, and a number of other limonoids isolated from several other plant species have also demonstrated larvicidal activity against larvae of Anopheles mosquito, ${ }^{9,29-31)}$ and the black blow fly Phormia regina ${ }^{32)}$ suggesting that these limonoids can be utilized to eradicate arthropods that are responsible for transmitting many diseases. Wandscheer et al. ${ }^{33)}$ have assayed limonoid extracts of Azadirachta indica and Melia azedarach against the larvae of dengue mosquito Aedes aegypti and suggest that by improving the extraction and fractionation of crude limonoids the larvicidal activity can be enhanced.

\section{PHARMACOLOGICAL ACTIVITIES}

Anti-cancer Activity Many experimental evidences have revealed that limonoids present in citrus fruits and their juice have cancer chemopreventive property, limonoids have been shown to inhibit the growth of estrogen receptor-negative and -positive human breast cancer cells in culture, limonoids have also been found to target and stop neuroblastoma cells. ${ }^{2,8,34-36)}$ Hesperidin, other flavonoids, limonin 17beta-D-glucopyranoside, and other limonoid glucosides are 


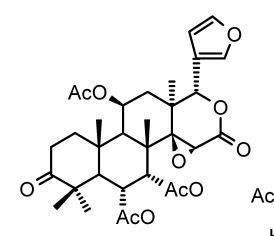

6a,11b-diacetoxygedunin

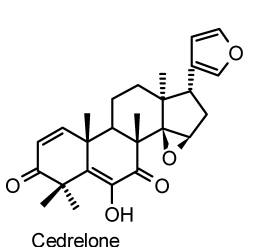

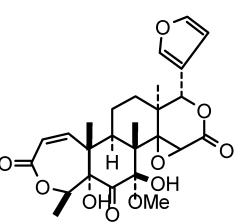

Harrisonine
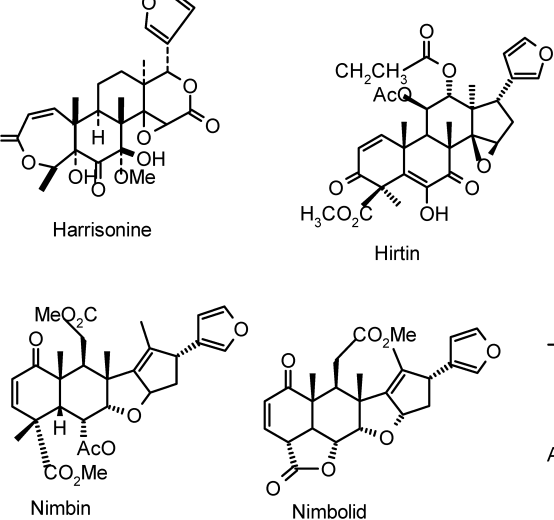

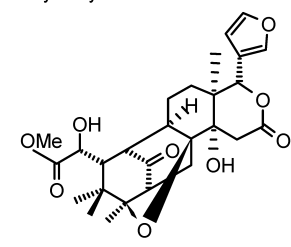

Cedrodorin

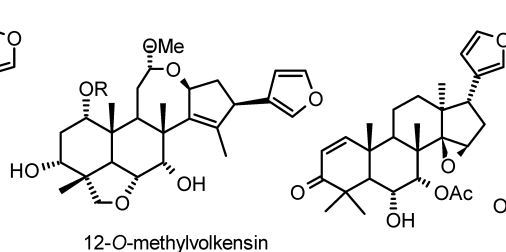

12-O-methylvolkensin

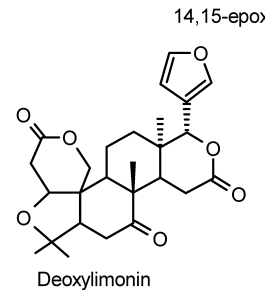

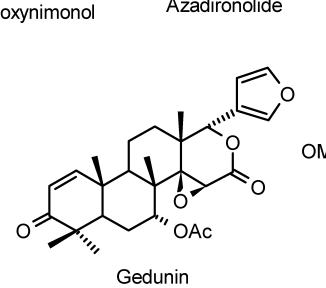

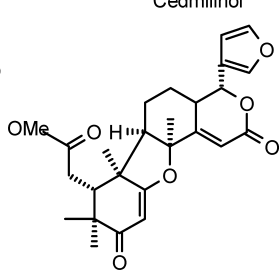

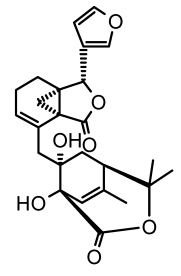

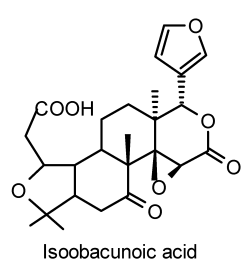

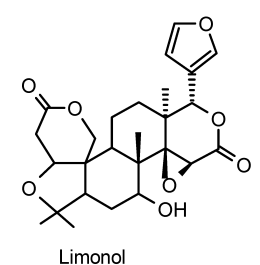

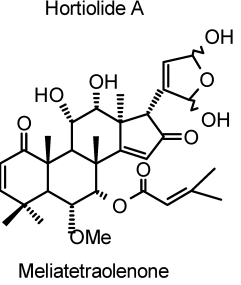

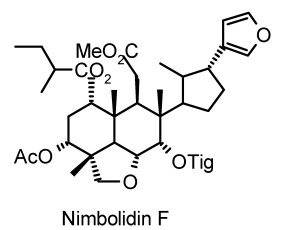

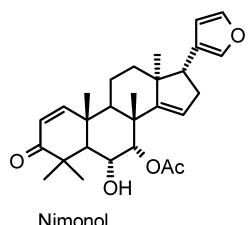

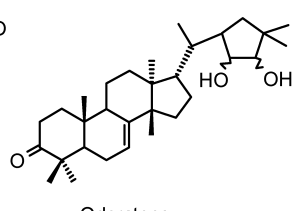

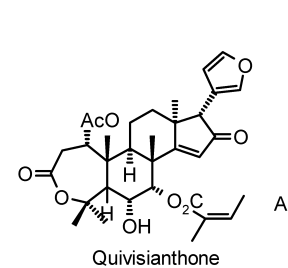

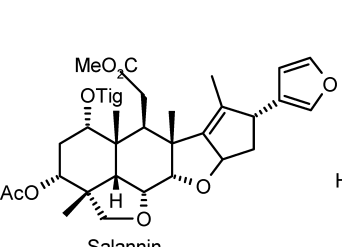<smiles>CC(C)=CCC[C@@H](C)[C@H]1CCC2(C)C3CCC4C(C)(CC[C@@H](O)C4(C)C)C3CC[C@]12C</smiles>

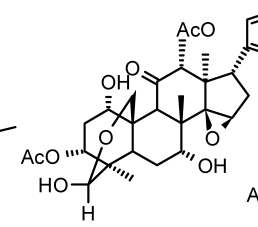
Toosendenin

Odoratone

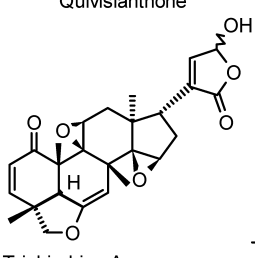

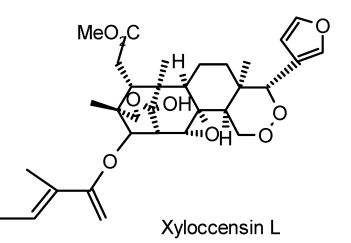

Fig. 6. Some Biologically Important Limonoids

potential chemopreventive agents in orange juice that could account for the decreased colon tumor-genesis associated with feeding orange juice. ${ }^{37)}$ Significant cytotoxic activity has also been exhibited by limonoids isolated from Melia azedarach, ${ }^{18)}$ Melia toosendan ${ }^{38)}$ and azadirachtin $\mathrm{A}^{39)}$

The citrus limonoids obacunone, limonin, nomilin and their glucosides and some aglycones inhibit chemically induced carcinogenesis and a series of human cancer cell lines, with remarkable cytotoxicity against lung, colon, oral and skin cancer in animal test system and human breast cancer cells. $^{5,14,40-44)}$ Obacunone was found to enhance the cytotoxicity of vincristine against L1210 cells by approximately 10fold. Further, it was found that the cytotoxicity of other microtubule inhibitors such as vinblastine and taxol in drugsensitive KB-3-1 cells as well as in multidrug-resistant $\mathrm{KB}-\mathrm{V} 1$ cells was enhanced greatly in the presence of obacunone. ${ }^{45)}$ Pure limonin glucoside and limonin, its water in- soluble relative lacking glucose, have been found to possess significant anti-tumor properties in animal tests and with human cells. ${ }^{14,46)}$ All these studies have reported the lack of toxicity of the limonoids in mammals and also have presented their modifying effect on the development of aberrant crypt foci, as well as ability of these compounds to induce specific carcinogen-metabolizing enzymes, glutathione Stransferace and quinine reductase in the liver and mucosa of the small intestine to detoxify chemical carcinogenesis. Studies show that the activity of phase II enzyme glutathione-Stransferase in the liver of the rats, fed diets containing limonin and nomilin, increased significantly in dose dependent manner. While simultaneously the limonoids nomilin and limonin were found to have no significant affect on the phase I enzyme Cytochrome P450. A dose dependent increase in small intestinal GST activity was also observed in nomilin fed animals, where as some citrus limonoids were able to in- 


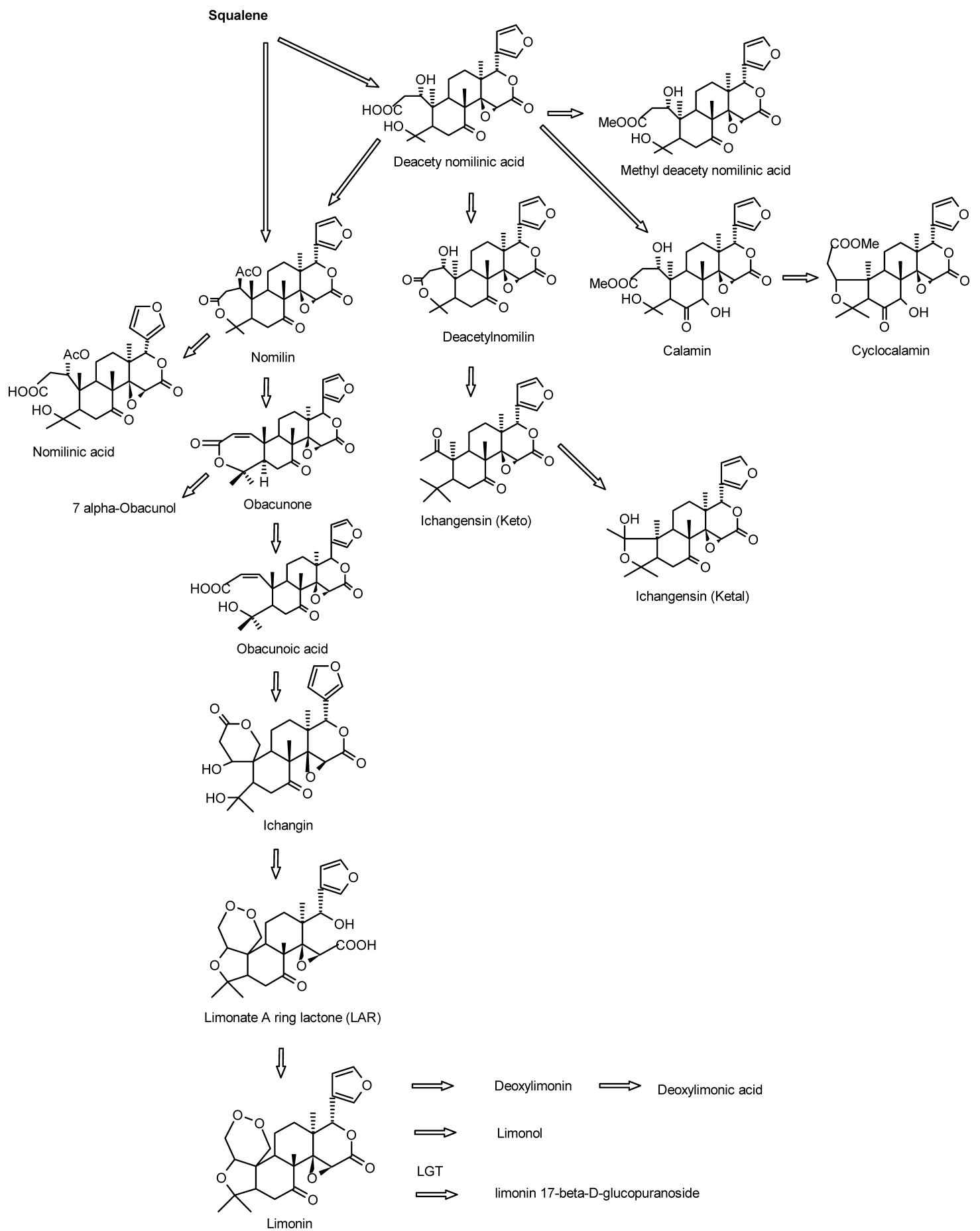

Fig. 7. Proposed Biosynthetic Pathways of Limonoids in Citrus

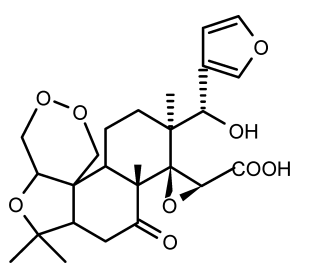

Limonate $\mathrm{A}$ ring lactone (Nonbitter)

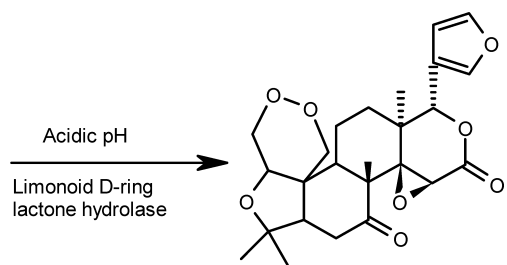

Lmonin (Bitter)

Fig. 8. Mechanism of Delayed Bitterness

hibit the development of 7,12-dimethylbenz [a]anthracene-induced oral tumors. The data from these studies have suggested that certain rings in the limonoid nucleus may be critical to antineoplastic activity. The results with deoxylimonin were significant, $p<0.05 .^{2)}$ Nutritional research on health benefits of chemicals present in plant foods advocate that citrus limonoids possess substantial anticancer activity and they are also free of any toxic effects in animal models. ${ }^{8)}$ Guthrie et $a l .{ }^{47)}$ were awarded a patent, recently, for proposing composition and methods for treatment of neoplastic diseases with limonoids in combination with flavonoids and tocotrienols. 
Table 2. Some Limonoids with Insect-Controlling Activity

\begin{tabular}{|c|c|c|}
\hline Limonoid/s & Type of activity & Reference \\
\hline $1 \beta, 2 \beta, 21,23$-Depoxy-7 $\alpha$-hydroxy-24,25,26,27-tetranor-apotriculla-14,20,22-trien-3-one & Antifeedant & 101 \\
\hline 12-Hydroxiamoorastatin & Antifeedant & 89 \\
\hline $6 \beta$-Hydroxygedunin alone and in combination with gedunin, salanin, nimbinene, azadirachtin & Growth inhibitory, antifeedant & 26 \\
\hline Azadirachtin & Fecundity and mortality & 113 \\
\hline Cedrodorin, 6-acetoxycedrodorin, 6-deoxy- $9 \alpha$-hydroxycedrodorin, $9 \alpha$-hydroxycedrodorin & Insect deterrent & 114 \\
\hline Dumnin and dumsenin & Antifeedant & 115 \\
\hline Hirtin, deacetylhirtin, and 3 novel limonoids & Antifeedant & 102 \\
\hline Khayanolide A and B, 1-O-acetylkhayanolide B & Antifeedant, growth inhibitory & 116 \\
\hline Khayanone, 2-hydroxyseneganolide, 1-O-acetylkhayanolide A & Antifeedant & 117 \\
\hline Meliartenin & Antifeedant & 20 \\
\hline Meliatetraolenone, odoratone & Insecticidal & 118 \\
\hline Photogedunin epimeric mixture, gedunin and cedrelanolide & Growth inhibitory & 119 \\
\hline Prieurianin, epoxyprieurianin & Antifeedant & 27 \\
\hline Salanin type & Antifeedant & 3 \\
\hline Tabulalides and tabulalides $\mathrm{A}-\mathrm{E}$ & Antifeedant & 84 \\
\hline Zumketol, zumsenin, zumsenol & Antifeedant & 120 \\
\hline Zumsin & Antifeedant & 121 \\
\hline
\end{tabular}

Anti-malarial Activity Gedunin, nimbin, nimbolide and many more limonoids isolated from Azadirachta indica, $\mathrm{Ce}$ drela odorata, Guarea mltiflora and Khaya grandifoliola have been identified for their in-vitro antimalarial activity on P. falciperum. ${ }^{48,49)}$ Gedunin was found to be most effective, against Plasmodium falciperum, out of several limonoids isolated from Khaya grandifoliola and it also exhibited additive effect in combination with Chloroquine. ${ }^{50)}$ Novel antimalarial limonoids were isolated following a veterinary and self-medicative behavioral survey of wild chimpanzees in Uganda, from leaves of Trichilia rubescens. ${ }^{51)}$

Anti-microbial Activity Germano et al ${ }^{52)}$ have recently reported the presence of limonoids in Trichilia emetica, which can be considered responsible for activity against many clinically, isolated bacterial strains. Limonoids obtained from some Khaya species, showed good antibacterial and antifungal activity. ${ }^{53,54)}$ In another study limonoids from several plants belonging to meliaceae as well as rutaceae family were reported to have significant antifungal activity. ${ }^{53,55,56)}$ In these studies the importance of structural features on activity is also illustrated.

Anti-HIV Activity Limonin and nomilin have shown to inhibit the replication of HIV-1 in a number of cellular systems. ${ }^{57)}$ A novel limonoid isolated from Clausena excavata have shown HIV-1 inhibitory activity. ${ }^{58)}$

Other Miscellaneous Activities Limonoid 1-cinnamoyl3,11-dihydroxymeliacarpin, isolated from Melia azedarach showed $\mathrm{IC}_{50}$ value of $6 \mu \mathrm{ml}$ and $20 \mu \mathrm{ml}$ for vesicular stomatitis and herpes simplex (HSV-1) viruses respectively. ${ }^{59)}$ Limonoids in Trichilia emetica were considered to be responsible for hepatoprotective activity on $\mathrm{CCl}_{4}$ induced damage in rat hepatocytes. Radical scavenging and anti-oxidant activity was demonstrated by some limonoids, which is supposed to play a role in their anti-proliferative activity. ${ }^{34,60)} \mathrm{A}$ reduction of low-density cholesterol in rabbits was observed after substituting orange juice and grapefruit juice for water. Further tests suggest that the limonoid contribute to cholesterol-lowering action of citrus juices. ${ }^{46}$ Raphael and Kut$\tan ^{61)}$ have reported immuno-modulatory activity of nomilin. Limonin is supposed to be specifically directed towards protection of lungs for clearing congestive mucus. ${ }^{62)}$ Zimmer$\operatorname{man}^{63)}$ has cited reports of cardioprotective effect of limonoids from mandarin oranges. In an in-vitro study, limonoids isolated from Swietenia humilis has exhibited a concentration dependant and non-reversible spasmogenic and uterotonic activity. ${ }^{64)}$ In-vitro anti-sickling activity of a rearranged limonoid isolated from Khaya senegalensis has been reported by Fall and co-workers, ${ }^{65)}$ they found the limonoid to have much higher activity at every concentration and incubation conditions, in comparison to the standard drug. Schmandke and Rehbrücke ${ }^{44)}$ have reported that some limonoids decrease cholesterol release in cultured human liver cells. Biswas et al. ${ }^{23)}$ in their review have reported a number of other pharmacological activities of limonoids derived from neem tree, like- anti-inflammatory, anti-arthritic, antipyretic, hypoglycemic, anti-gastric ulcer, spermicidal and diuretic.

Cedrelanolide, the most abundant limonoid from Cedrela salvadorensis has shown to interfere with monocot pre-emergence properties and also inhibits their photophosphorylation, $\mathrm{H}^{+}$uptake and non-cyclic electron flow which results in inhibition of germination, seed respiration and seedling dry weights of some plant species. ${ }^{66)}$

\section{STRUCTURE ACTIVITY RELATIONSHIPS}

Madyastha and Venkatakrishnan ${ }^{67)}$ have described the studies carried out on the structure-activity relationships amongst limonoids, showing that limonoids with an intact apoeuphol skeleton, a $14,15 \beta$ epoxide, and a reactive site such as either a 19-28 lactol bridge or a cyclohexanone ' $A$ ' ring are biologically very active and absence of these structural features results in reduced activity; $C$-seco limonoids with an enone system in ring ' $\mathrm{A}$ ' are potent cytotoxic and anti-malarial agents, in some of these (e.g. nimbolide 5,28deoxonimbolide and gedunin) $\alpha, \beta$-unsaturated ketone in ring ' $A$ ' has been proposed as common feature that is primarily responsible for their biological activity. They further say that the $C$-seco limonoids are two to three times more active than other limonoids and they are highly active against herbivorous insects. Data from the studies conducted by Miller et $a l .{ }^{35)}$ have suggested that certain rings in the limonoid nucleus may be critical to anti-neoplastic activity. Changes in the A ring of the limonoid nucleus can lead to a loss of anti- 
cancer activity, whereas changes in the D ring can be tolerated without any apparent loss of biological activity.

Studies carried out on azadirachtin and some of its derivatives as insect feeding deterrents that revealed that neither hydrogenation of $\Delta^{22}$ double bonds nor deacetylation caused any change in effect but blocking of hydroxyl group affected the feeding inhibitory activity, while acetylation of azadirachtin caused a decrease in the activity to $75 \%$, etherification with a bulky trimethylsilyl group eliminated it altogether. Thus, the stereochemical environment around hemiacetal region seemed to be critical for its activity. ${ }^{1)}$ Screening of eight derivatives of azadirachtin for their insect growth-inhibitory effect on first instar larvae of tobacco bud worm (Heliothis virescens) gave similar conclusion that the free hydroxyls are essential for maximum activity. On comparing the relative efficacy of isomeric azadirachtins and their derivatives for growth inhibition of larvae of the Mexican beetle (Epilachna varivestis) it was found that $\mathrm{LC}_{50}$ values (ppm) were 1.66, 1.30, 12.97, 1.57, 2.80, 1.15, and 7.69 for azadirachtins $A-G$ respectively. Interestingly, 3-detigloylazadirachtin $\mathrm{B}$ was the most active with $\mathrm{LC}_{50}$ value of $0.08 \mathrm{ppm}$ and the hydrogenated derivatives were more active than the parent molecules. On structural modifications and screening the new products for insect feeding deterrent action following conclusions were derived: even a simple analogue retaining the hydroxydihydrofuran portion of the molecule was $50-60 \%$ as active as azadirachtin. Compounds showing gross structural rearrangements of this portion were less active. Considering the structural homology with salannin, the uniquely high level of activity of azadirachtin apparently stems from the hydroxydihydrofuran portion of the molecule. $^{1,2)}$

In structure-activity studies of limonin, it has been determined that the furan ring and epoxide groups in the citrus limonoid structure are critical for the antifeedant activity of the limonoids against Colorado potato beetle larvae. ${ }^{12)} \mathrm{Ru}$ berto et $\mathrm{al}^{28)}$ evaluated the antifeedant activity of citrus-derived limonoids limonin, nomilin, and obacunone and their semisynthetic derivatives against a commercially important pest, Spodoptera frugiperda. These conversions focused on functional groups considered being important for the biological activity, namely the $\mathrm{C}-7$ carbonyl and the furan ring. In particular, reduction at C-7 afforded the related alcohols, and from these their acetates, oximes, and methoximes were prepared. Hydrogenation of the furan ring was also performed on limonin and obacunone and on comparison with previously reported data it showed that insect species vary in their behavioral responses to these structural modifications. Highly significant antifeedant activity $(p<0.01)$ for two natural (limonin and obacunone) and three semisynthetic limonoids (Umonol, Umonin-7-oxime, and Limonin-7-oxime acetate) was observed against $S$. frugiperda.

\section{ROLE IN BITTERNESS OF CITRUS FRUITS AND ITS SOLUTION}

Citrus fruits are accepted for their nutritive and medicinal value as well as for providing distinctive flavor to a wide variety of food products, making it very popular among food product designers. But, a major problem in the citrus industry worldwide is the formation of bitterness in citrus juice and products within hours after extraction of juice. This bitterness occurs in certain varieties of oranges, grapefruits and lemons having a significant negative impact commercially. Bagge $^{6}$ in his review has reported that the reason for delayed bitterness of citrus juice is due to the conversion of limonateA-ring lactone, which is present in the carpellary membrane and albido tissue of fruits, into limonin. This reaction proceeds under acidic conditions below $\mathrm{pH} 6.5$ and is accelerated by the enzyme limonin-D-ring lactone hydrolase (Fig. 7).

Cause for bitterness of citrus fruits has been attributed to the presence of limonin, nomilin and to some extent to ichangin. ${ }^{4,68)}$ The same reports state that their concentration decrease during the process of ripening due to conversion of limonoids into corresponding non-bitter glucosides by the activity of glucoside synthesizing enzyme, limonoid glucosyl transferase (LGTase). Kita et al. ${ }^{69)}$ have isolated a cDNA clone (Cit LGT), which encodes LGTase. According to them Cit LGT is present as a single copy of gene in the citrus genome and the amount of transcript corresponding to Cit LGT mRNA changes the same way as the fluctuation of limonin glucoside content during fruit development of navel orange, indicating that the transcription of Cit LGT regulates the conversion of limonoid aglycones to glucosides in citrus fruits. Endo et al. ${ }^{4)}$ and Karim and Hashinaga ${ }^{68)}$ therefore propose that bitterness in citrus fruits can be reduced by manipulating enzyme activity at molecular level; they also suggest that LGTase gene can be introduced to bacterial cells, which can then be used in column as immobilized cells to convert free limonoids into glucoside. The development of a plant regeneration system for purpose of genetic engineering has been reported and it has been shown that embryos can be obtained from embryogenic callus by change of culture medium and embryogenic calli can be transformed by an Agrobacterium mediated method. Thus, genetic engineering of citrus to maximize the formation of limonoid glucosides for reducing limonoid bitterness could be targeted. ${ }^{4)}$

\section{ADDITIONAL FINDINGS}

The health benefits of limonoids have made the scientists to find methods to synthesize them in laboratory. ${ }^{70)}$ Patents have been obtained for industrial scale method for manufacturing limonoid glucosides contained in citrus fruit. ${ }^{71)}$ Scientists are trying to design food products, fortified with limonoids to provide prophylactic benefits against cancer and many other diseases. ${ }^{15)}$ Methods are also been established to purify limonoids ${ }^{72}$ and increase their yields through better extraction procedures. ${ }^{73)}$ But caution has been advocated in consumption of limonoids as they may interfere with activity of other drugs ${ }^{74)}$ or may even produce harmful effects if consumed in very high quantities. ${ }^{75)}$ But except for a few exceptions in most of the studies long term consumption of limonoids have produced no adverse effects and have been found to be safe. ${ }^{8,14)}$ It has also been suggested that limonoids may interact with other bioactive components present in fruits and vegetables and may reduce the risk of degenerative diseases, hypertension, cataract, and stroke and in particular cancers. ${ }^{40)}$ 


\section{CONCLUSION}

Limonoids are an important group of metabolically altered triterpene, which are limited in their distribution. In recent years a large number of pharmacological studies have been carried out to indicate their beneficial effects. The medicinal properties reported include anti-cancer, anti-malarial, antimicrobial, anti-HIV, anti-viral and several others. Post-study health evaluation has established no ill effects among study subjects consuming high doses of limonin glucoside. Some of them have also shown allelopathic potential.

The citrus limonoids exhibit promising health benefits (anti-cancer, cardioprotective, anti-oxidant etc.) but are the major cause of concern due to their extreme bitterness. There is a need to develop an acceptable and versatile debittering method that can substantially remove or mitigate the bitterness of fruits and juice.

Azadirachta indica, a related plant Melia azedarach, along with several other plant species belonging to meliaceae family are a store-house of limonoids like azadirachtin and other related compounds that have feeding deterrent, insect-repellant, anti-hormone and other insect control properties against bulk of insect pests. They are also useful as larvicides for destroying larvae of Anopheles mosquito. Such reports provide an impetus to evaluate these compounds alone or in combination to identify their potential in commercial formulations that can be used as bio-pesticides in integrated pest management. However, because these are high cost biochemicals and at the same time complexicity of structures precludes their synthesis, hence biotechnology and tissue culture techniques may be extensively investigated to enhance their production to meet the increasing demands.

Regarding the biological activities of limonoids the focus is to be directed towards detailed characterization, quantification, and designing a simple as well as versatile synthetic route of apparently important limonoids. Extraction methods too should be optimized; evaluation and establishment of pharmaco-dynamic and kinetic principles, and structure activity relationships should be a key goal associated with limonoids so that they can be safely introduced in our arsenal of pharmaceuticals to safeguard the humanity from the wrath of disease and its discomfort.

\section{REFERENCES AND NOTES}

1) Devakumar C., Sukh Dev, “Chemistry,” ed. by Randhawa N. S., Parmar B. S., Neem Research and Development, Society of Pesticide Science, New Delhi, India, 1996, pp. 63-99.

2) Anonymous, Available at: http://webtutor.tamu.edu/students/vikram/ project/limonoid.html; Accessed on 27/07/2005.

3) Koul O., Singh G., Singh R., Daniewski W. M., Berlozecki S., J. Biosci., 29, 409-416 (2004).

4) Endo T., Kita M., Shimada T., Moriguchi T., Hidaka T., Matsumoto R., Hasegawa S., Omura M., Plant Biotechnol., 19, 397-403 (2002).

5) Nakagawa H., Duan H., Takaishi Y., Chem. Pharm. Bull., 49, 649651 (2001).

6) Bagge D., Available at: http://www.colostate.edu/Depts/ Entomology/courses/en570/papers_1998/bagge.htm; Accessed on 15/04/2005.

7) Moriguchi T., Kita M., Hasegawa S., Omura M., Food Agric. Environment, 1, 22-25 (2003).

8) Jacob R., Hasegawa S., Manners G., Perishables Handling, 102, 68 (2000).
9) Aliero B. L., African J. Biotechnol., 2, 325-327 (2003).

10) Waterman P. G., "Evolution of Secondary Plant Metabolism," Encyclopedia of Life Sciences, Nature Publishing Group, 2001, Available at: www.els.net; Accessed on 16/07/2005.

11) Suarez L. E. C., Menichini F., Monache F. D., J. Braz. Chem. Soc., 13, 339-344 (2002).

12) Danielson E. J., Available at: http://www.colostate.edu/Depts/ Entomology/courses/en570/papers_1996/danielson.html; Accessed on 10/04/2005.

13) Hasegawa S., Miyake M., Food Rev. Int., 12, $413-435$ (1996).

14) Manners G. D., Jacob R. A., Breksa Iii A. P., Hasegawa S., Schoch T. K., J. Agric. Food Chem., 51, 4156-4161 (2003).

15) Charleston D., Plant Protection News, 60, 7 -9 (2002).

16) Kraus W., "Azadirachtin and Other Triterpenoids," ed. by Schmutterer H., The Neem Tree. Source of Unique Natural Products for Integrated Pest Management, Medicine, Industry and Other Purposes, VCH, Weinheim, Germany, 1995, pp. 34-74.

17) Somrutai J., Chantachum S., Ratanaphan A., Chantrapromma K., Available at: http://ejeafche.uvigo.es/4(3) 2005/432005.pdf; Accessed on 12/09/2005.

18) Okamura H., Yamauchi K., Iwagawa T., Nakatani M., Tetrahedron Lett., 38, 263-266 (1997).

19) Breksa A. P., 3rd, Zukas A. A., Manners G. D., J. Chromatogr. A, 1064, 187-191 (2005).

20) Carpinella C., Ferrayoli C., Valladares G., Defago M., Palacios S., Biosci. Biotechnol. Biochem., 66, 1731-1736 (2002).

21) Schaaf O., Jarvis A. P., Andrew van der Esch S., Giagnacovo G., Oldham N. J., J. Chromatogr. A, 886, 89-97 (2000).

22)* National Research Council, Neem: A Tree for Solving Global Problems. National Academy Press, Washington, D. C., Available at: http://www.nap.edu/catalog/1924.html; Accessed on 15/04/2005.

23) Biswas K., Chattopadhyay I., Banerjee R. K., Bandopadhyay U., Curr. Sci., 11, 1336-1345 (2002).

24) Jarvis P. A., Morgan E. D., Phytochem. Anal., 11, 184-189 (2000).

25) Ignacimuthu S., Curr. Sci., 86, 1059-1060 (2004).

26) Koul O., Multani J. S., Singh G., Daniewski W. M., Berlozecki S., J. Agric. Food Chem., 51, 2937-2942 (2003).

27) Koul O., Daniewski W. M., Multani J. S., Gumulka M., Singh G., J. Agric. Food Chem., 51, 7271-7275 (2003).

28) Ruberto G., Renda A., Tringali C., Napoli E. M., Simmonds M. S., J. Agric. Food Chem., 50, 6766-6774 (2002).

29) Ndung'u M., Torto B., Knols B. G. J., Hassanali A., Int. J. Tropical Insect Sci., 24, 311-318 (2004).

30) Ndung'u M. W., Kaoneka B., Hassanali A., Lwande W., Hooper A. M., Tayman F., Zerbe O., Torto B., J. Agric. Food Chem., 52, 5027-5031 (2004).

31) Ndung'u M., Hassanali A., Hooper A. M., Chhabra S., Miller T. A., Paul R. L., Torto B., Phytochemistry, 64, 817-823 (2003).

32) Simmonds W. M. S., Blaney W. M., Khambay B. P., Phytother. Res., 18, 538-541 (2004).

33) Wandscheer C. B., Duque J. E., da Silva M. A., Fukuyama Y., Wohlke J. L., Adelmann J., Fontana J. D., Toxicon, 44, 829-835 (2004).

34) Poulose S. M., Harris E. D., Patil B. S., J. Nutr., 135, 870-877 (2005).

35) Miller E. G., Porter J. L., Binnie W. H., Guo I. Y., Hasegawa S., J. Agric. Food Chem., 52, 4908-4912 (2004).

36) Tian Q., Miller E. G., Ahmad H., Tang L., Patil B. S., Nutr. Cancer, 40, 180-184 (2001)

37) Miyagi Y., Om A. S., Chee K. M., Bennink M. R., Nutr. Cancer, 36, $224-229$ (2000).

38) Tada K., Takido M., Kitanaka S., Phytochemistry, 51, 787-791 (1999).

39) Akudugu J., Gade G., Bohm L., Life Sci., 68, 1153-1160 (2001).

40) Silalahi J., Asia Pac. J. Clin. Nutr., 11, 79-84 (2002).

41) "Citrus Limonoids: Functional Chemicals in Agriculture and Foods," ed. by Berhow M. A., Hasegawa S., Manners G. D., American Chemical Society, Washington, D.C., 2000.

42) Tanaka T., Maeda M., Kohno H., Murakami M., Kagami S., Miyake M., Wada K., Carcinogenesis, 22, 193-198 (2001).

43) Tanaka T., Kohno H., Tsukio Y., Honjo S., Tanino M., Miyake M., Wada K., Biofactors, 13, 213-218 (2000).

44) Schmandke H., Rehbrücke B., Available at: http://www.ernaehrungs-umschau.de/archiv/summaries/?page $=2 \& i d=1372 ; \quad$ Accessed 
on $25 / 09 / 2005$.

45) Jung H. J., Sok D. E., Kim Y. H., Min B. S., Lee J. P., Bae K.-H., Planta Med., 66, 74-76 (2000).

46) Manners G. D., Hasegawa S., International Society of Citriculture Proceedings, Proceedings 2000, 2000, pp. 1195-1197.

47) Guthrie N., Elzbieta Maria V., Carroll Kenneth Kitchener C. K. (Inventors); Compositions and methods of treatment of neoplastic diseases and hypercholesterolemia with citrus limonoids and flavonoids and tocotrienols; Patent Number: US6251400; Publication date: 2001-06-26.

48) Kayser O., Kiderlen A. F., Croft S. L., Parasitol. Res., 90, S55S62 (2003).

49) Saxena S., Pant N., Jain D. C., Bhakuni R. S., Curr. Sci., 85, 1314 1329 (2003).

50) Bickii J., Njifutie N., Ayafor Foyere J., Basco L. K., Ringwald P., J. Ethnopharmacology, 69, 27-33 (2000).

51) Krief S., Martin M. T., Grellier P., Kasenene J., Sevenet T., Antimicrob. Agents Chemother., 48, 3196-3199 (2004).

52) Germano M. P., D’Angelo V., Sanogo R., Catania S., Alma R., De Pasquale R., Bisignano G., J. Ethnopharmacology, 96, 227-232 (2005)

53) Abdelgaleil S. A., Hashinaga F., Nakatani M., Pest Manag. Sci., 61, 186-190 (2005).

54) Abdelgaleil S. A., Iwagawa T., Doe M., Nakatani M., Fitoterapia, 75, 566-572 (2004).

55) Govindachari T. R., Suresh G., Gopalakrishnan G., Masilamani S., Banumathi B., Fitoterapia, 71, 317-320 (2000).

56) Govindachari T. R., Suresh G., Banumathy B., Masilamani S., Gopalakrishnan G., Kumari G. N. K., J. Chem. Ecol., 25, 923-933 (1999).

57) Battinelli L., Mengoni F., Lichtner M., Mazzanti G., Saija A., Mastroianni C. M., Vullo V., Planta Med., 69, 910-913 (2003).

58) Sunthitikawinsakul A., Kongkathip N., Kongkathip B., Phonnakhu S., Daly J. W., Spande T. F., Nimit Y., Napaswat C., Kasisit J., Yoosook C., Phytother. Res., 17, 1101-1103 (2003).

59) Alche L. E., Ferek G. A., Meo M., Coto C. E., Maier M. S., Z. Nat. forsch. C, 58, 215-219 (2003).

60) Yu J., Wang L., Walzem R. L., Miller E. G., Pike L. M., Patil B. S., J. Agric. Food Chem., 53, 2009-2014 (2005).

61) Raphael T. J., Kuttan G., Phytomedicine, 10, 483 - 489 (2003).

62) Rohr A. C., Wilkins C. K., Clausen P. A., Hammer M., Nielsen G. D., Walkoff P., Spengler J. D., Inhalation Toxicol., 14, 663-684 (2002)

63) Zimmerman M. C. N., Available at: http://exchange.healthwell.com/ nutritionsciencenews/nsn_backs/Jul_00/phytochemicals.cfm; Accessed on 23/09/2005.

64) Perusquia M., Hernandez R., Jimenez M. A., Pereda-Miranda R., Mata R., Phytother. Res., 11, 354-357 (1998).

65) Fall A. B., Vanhaelen-Faster R., Vanhaelen M., Lo I., Toppet M., Ferster A., Fondu P., Planta Med., 65, 209-212 (1999).

66) Cespedes C. L., Calderon J. S., Salazar J. R., Lotina-Hennsen B., Segura R., J. Chem. Ecol., 27, 137-149 (2001).

67) Madyastha M. K., Venkatakrishnan K., J. Chem. Soc., Perkin Trans 1, 2000, 3055-3062 (2000)

68) Karim M. R., Hashinaga F., Pakistan J. Biol. Sci., 4, 486-483 (2001).

69) Kita M., Hirata Y., Moriguchi T., Matsumoto R., Hasegawa S., Suhayada C. G., Omura M., FEBS Lett., 469, 173-178 (2000).

70) Fernandez-Mateos A., Martin de la Nava E. M., Gonzalez R. R., Synthesis J. Synthetic Organic Chem., 12, 1728-1734 (2002).

71) Hasegawa S., Miyake M., Available at: http://ars.usda.gov/research/ patents/patents.htm?serialnum $=08595607$; Accessed on $10 / 04 /$ 2005 .

72) Sunthanont K., Bennink M. R., Uebersax M. A., Available at: http://ift.confex.com/ift/2002/techprogram/paper_14285.htm; Accessed on 25/09/2005.

73) Miyake M., Ifuku Y., Available at: http://www.ffcr.or.jp/zaidan/ FFCRHOME.nsf/; Accessed on 10/04/2005.

74) Lien E. J., Wang T., Lien L. L., Available at: http://jwc1.mc.ntu. edu.tw/cpj/Material/54-2/542077abs.htm; Accessed on 21/09/ 2004.

75) Gibbins R. P., Miller E. G., Taylor S. E., Mcintosh J. E., Patil B. S., Available at: http://iadr.confex.com/iadr/2004Hawaii/techprogram/ abstract 38997.htm; Accessed on 27/07/2005.
76) Puripattanavong J., Weber S., Brecht V., Frahm A. W., Planta Med., 66, 740-745 (2000).

77) Mulholland D. A., Randrianarivelojosia M., Lavaud C., Nuzillard J. M., Schwikkard S. L., Phytochemistry, 53, 115-118 (2000).

78) Hallur G., Sivaramakrishnan A., Bhat S. V., J. Nat. Prod., 65 1177-1179 (2002).

79) Malathi R., Rajan S. S., Gopalakrishnan G., Suresh G., Acta Crystallogr. C, 58, 708-710 (2002).

80) Siddiqui B. S., Afshan F., Ghiasuddin, Faizi S. N., Tariq R. M., Phytochemistry, 53, 371-376 (2000).

81) Saxena E., Babu U. V., Fitoterapia, 72, 186-187 (2001).

82) Castellanos L., de Correa R. S., Martinez E., Calderon J. S., Z. Nat. forsch. C, 57, 575-578 (2002).

83) Mitsui K., Maejima M., Fukaya H., Hitotsuyanagi Y., Takeya K., Phytochemistry, 65, 3075-3081 (2004).

84) Nakatani M., Abdelgaleil S. A., Saad M. M., Huang R. C., Doe M., Iwagawa T., Phytochemistry, 65, 2833-2841 (2004).

85) Leite A. C., Oliveira C. G., Fernandes J. B., Vieira P. C., da Silva M. F. G. F., Hebling M. J. A., Pagnocca F. C., Bueno O. C., Available at: http://www.bnp2004.com/p/p94.pdf; Accessed on 21/09/2004.

86) Tchimene M. K., Tane P., Ngamga D., Connolly J. D., Farrugia L. J., Phytochemistry, 66, 1088-1093 (2005).

87) Nakatani M., Abdelgaleil S. A., Kassem S. M., Takezaki K., Okamura H., Iwagawa T., Doe M., J. Nat. Prod., 65, 1219-1221 (2002).

88) Zhou H., Hamazaki A., Fontana J. D., Takahashi H., Esumi T., Wandscheer C. B., Tsujimoto H., Fukuyama Y., J. Nat. Prod., 67, 1544-1547 (2004).

89) Carpinella M. C., Defago M. T., Valladares G., Palacios S. M., J. Agric. Food Chem., 51, 369-374 (2003).

90) Koul O., Multani J. S., Singh G., Wahab S., Curr. Sci., 83, 1387 1391 (2002).

91) Zhang H. P., Bao G. H., Wang H. B., Qin G. W., Nat. Prod. Res., 18, 415-419 (2004).

92) Coombes P. H., Mulholland D. A., Randrianarivelojosia M., J. Nat. Prod., 66, 735-738 (2003).

93) Vardamides J. C., Dongo E., Nkengfack A. E., Fomum Z. T., Ngando T. M., Vogler B., Kraus W., Fitoterapia, 72, 386-393 (2001).

94) Coombes P. H., Mulholland D. A., Randrianarivelojosia M., Phytochemistry, 65, 377-380 (2004).

95) Coombes P. H., Mulholland D. A., Randrianarivelojosia M., Phytochemistry, 66, 1100-1107 (2005).

96) Ismail I. S., Ito H., Hatano T., Taniguchi S., Yoshida T., Phytochemistry, 64, 1345-1349 (2003).

97) Ismail I. S., Ito H., Hatano T., Taniguchi S., Yoshida T., Chem. Pharm. Bull., 52, 1145-1147 (2004).

98) Saad M. M. G., Iwagawa T., Doe M., Nakatani M., Tetrahedron, 59, 8027 -8033 (2003).

99) Soundarya Devi S., Malathi R., Rajan S. S., Aravind S., Krishnakumari G. N., Ravikumar K., Acta Crystallogr., C59, 530-532 (2003).

100) Cortez D. A., Fernandes J. B., Vieira P. C., da Silva M. F., Ferreira A. G., Phytochemistry, 55, 711-713 (2000).

101) Rodriguez B., Caballero C., Ortego F., Castanera P., J. Agric. Food Chem., 51, 369-374 (2003).

102) Simmonds M. S., Stevenson P. C., Porter E. A., Veitch N. C., J. Nat. Prod., 64, 1117-1120 (2001).

103) McFarland K., Mulholland D. A., Fraser L. A., Phytochemistry, 65, 2031-2037 (2004).

104) Wu J., Zhang S., Xiao Q., Li Q., Huang J., Long L., Huang L., Tetrahedron Lett., 45, 591-593 (2004).

105) Wattanapiromsakul C., Forster P. I., Waterman P. G., Phytochemistry, 64, 609-615 (2003).

106) Khalil A. T., Maatooq G. T., El Sayed K. A., Z. Nat. forsch. C, 58, $165-170$ (2003).

107) Sawabe A., Morita M., Kiso T., Kishine H., Ohtsubo Y., Minematsu T., Matsubara Y., Okamoto T., Carbohydr. Res., 315, 142-147 (1999).

108) Zhao W., Wolfender J. L., Hostettmann K., Xu R., Qin G., Phytochemistry, 47, 7-11 (1998).

109) Biavatti M. W., Vieira P. C., da Silva M. F., Fernandes J. B., Albuquerque S., Z. Nat. forsch. C, 56, 570-574 (2001).

110) Rugutt J. K., Rugutt K. J., Berner D. K., J. Nat. Prod., 64, 1424 
1428 (2001).

111) Khuong-Huu Q., Chiaroni A., Riche C., Nguyen-Ngok H., NguyenViet K., Khuong-Huu F., J. Nat. Prod., 64, 634-637 (2001).

112) Chiaroni A., Riche C., Khuong-Huu Q., Nguyen-Ngoc H., NguyenViet K., Khuong-Huu F., Acta Crystallogr., C56, 711-713 (2000).

113) Martinez-Villar E., Saenz-De-Cabezon F. J., Moreno-Grijalba F., Marco V., Perez-Moreno I., Exp. Appl. Acarol., 35, 215-222 (2005).

114) Veitch N. C., Wright G. A., Stevenson P. C., J. Nat. Prod., 62, 1260-1263 (1999).

115) Nihei K., Asaka Y., Mine Y., Ito C., Furukawa H., Ju-Ichi M., Kubo I., J. Agric. Food Chem., 52, 3325-3328 (2004).

116) El-Aswad A. F., Abdelgaleil S. A., Nakatani M., Pest Manag. Sci.,
60, 199-203 (2004).

117) Nakatani M., Abdelgaleil S. A., Kurawaki J., Okamura H., Iwagawa T., Doe M., J. Nat. Prod., 64, 1261-1265 (2001).

118) Siddiqui B. S., Afshan F., Gulzar T., Sultana R., Naqvi S. N., Tariq R. M., Chem. Pharm. Bull., 51, 415-417 (2003).

119) Cespedes C. L., Calderon J. S., Lina L., Aranda E., J. Agric. Food Chem., 48, 1903-1908 (2000).

120) Nihei K., Asaka Y., Mine Y., Kubo I., J. Nat. Prod., 68, 244-247 (2005).

121) Nihei K., Hanke F. J., Asaka Y., Matsumoto T., Kubo I., J. Agric. Food Chem., 50, 5048-5052 (2002).

* Cited as recommended by publisher. 